\title{
Comparison of Splenectomy and Eltrombopag Treatment in the Second-Line Treatment of Immune Thrombocytopenic Purpura
}

\author{
İmmün Trombositopenik Purpuranın İinci Basamak Tedavisinde Splenektomi ve \\ Eltrombopag Tedavilerinin Karşılaştııılması
}

\begin{abstract}
(D) Mehmet Can Uğur ${ }^{1}$, (D) Sinem Namdaroğlu1, (D) Esma Evrim Doğan², (D) Esra Turan Erkek³, (D) Nihan Nizam, (D) Rafet Eren¹, (D) Oktay Bilgir1

1 University of Health Sciences Turkey, Izmir Bozyaka Training and Research Hospital, Clinic of Hematology, Izmir, Turkey

2 University of Health Sciences Turkey, Prof. Dr. Cemil Taşçığlu Training and Research Hospital, Clinic of Hematology, İstanbul, Turkey

3 University of Health Sciences Turkey, Izmir Dr. Lütfi Kırdar Training and Research Hospital, Clinic of Hematology, Istanbul, Turkey

4 izmir Çiğli Training and Research Hospital, Clinic of Internal Medicine, İzmir, Turkey
\end{abstract}

\section{Abstract}

Objective: Primary immune thrombocytopenia (ITP) is an acquired autoimmune disease characterized by isolated thrombocytopenia. While first-line treatments focus on inhibiting autoantibodies and platelet destruction, second- and third-line treatments include splenectomy and thrombopoietin receptor agonists. In this study, we aimed to compare the efficiency and toxicities of splenectomy and eltrombopag as second-line treatments in ITP.

Materials and Methods: We retrospectively analyzed patients who were diagnosed with ITP and followed between 2015 and 2020. Patients who underwent splenectomy or received eltrombopag treatment as second-line or further therapy were included. For subgroup analyses, patients were further stratified according to whether they received eltrombopag in the second or third line of treatment.

Results: There were 38 patients in the splenectomy group and 47 patients in the eltrombopag group. The mean age of patients in the splenectomy and eltrombopag groups was 43.2 and 50.5 years, respectively. Time to response was significantly shorter in the splenectomy arm $(p=0.001)$. However, response rates at the $3^{\text {rd }}, 6^{\text {th }}, 12^{\text {th }}$, and $24^{\text {th }}$ months did not exhibit a statistically significant difference between groups; nor did total duration of response and adverse events. Response rates at the $1^{\text {st }}, 3^{\text {rd }}, 6^{\text {th }}, 12^{\text {th }}$, and $24^{\text {th }}$ months and the total duration of response did not exhibit a statistically significant difference between eltrombopag subgroups. Eltrombopag treatment was ceased for 20 patients after a median of 54.1 months (range: 1-151). Among them, 12 patients (60\%) did not experience a loss of response.

Conclusion: Comparing the splenectomy and eltrombopag arms, even though time to achieve response was in favor of the splenectomy group, this advantage disappeared when overall response rates and response rate at the $2^{\text {nd }}$ year were considered. Using eltrombopag in the second or third line of therapy does not yield any difference in terms of time to achieving response.

Keywords: Thrombocytopenia, Eltrombopag, Splenectomy

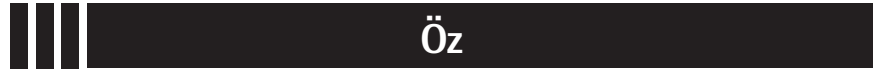

Amaç: Primer immün trombositopeni (ITP), izole trombositopeni ile karakterize, edinsel bir otoimmün hastalıktır. Birinci basamak tedaviler otoantikorları ve trombosit yıkımını inhibe etmeye odaklanırken, ikinci ve üçüncü basamak tedaviler arasında splenektomi ve trombopoietin reseptör agonistleri bulunur. Bu çalışmada, ITP'de ikinci basamak tedaviler olarak splenektomi ve eltrombopagın etkinlik ve toksisitelerinin karşılaştırılması amaçlanmıştır.

Gereç ve Yöntemler: 2015-2020 yılları arasında ITP tanısı alan ve takip edilen hastaları retrospektif olarak analiz ettik. Splenektomi yapılan ve 2. veya daha ileri basamaklarda eltrombopag tedavisi alan hastalar çalışmaya dahil edildi. Alt grup analizleri için, hastalar ikinci veya üçüncü tedavi hattında eltrombopag alıp almadıklarına göre gruplandırıldı.

Bulgular: Splenektomi grubunda 38 hasta, eltrombopag grubunda 47 hasta vardı. Splenektomi ve eltrombopag gruplarındaki hastaların ortalama yaşı sırasıyla 43,2 ve $50,5^{\prime}$ di. Splenektomi kolunda yanıt süresi anlamlı olarak daha kısaydı $(p=0,001)$. Bununla birlikte, 3., 6 ., 12. ve 24. aylardaki yanıt oranları, toplam yanıt süresi ve yan etkiler açısından gruplar arasında istatistiksel olarak anlamlı fark bulunmadı. Birinci, 3., 6., 12. ve 24. aylardaki yanıt oranları ve toplam yanıt süresi, eltrombopag alt grupları arasında istatistiksel olarak anlamlı değildi. Eltrombopag tedavisi medyan 54,1 ay $(1-151)$ sonra 20 hastada kesildi. Bunlardan 12 hastada (\%60) yanıt kaybı yaşanmadı.

Sonuç: Splenektomi ve eltrombopag kolları karşılaştırıldığında yanıt alma süresi splenektomi lehine olsa da, genel yanıt oranları ve 2. yıldaki yanıt oranları dikkate alındığında bu avantaj ortadan kalkmaktadır. İkinci veya 3. basamak tedavide eltrombopag kullanılması, yanıt alma süresi açısından herhangi bir fark oluşturmamaktadır.

Anahtar Sözcükler: Trombositopeni, Eltrombopag, Splenektomi

๑Copyright 2021 by Turkish Society of Hematology

Turkish Journal of Hematology, Published by Galenos Publishing House

Address for Correspondence/Yazışma Adresi: Mehmet Can Uğur, M.D., University of Health Sciences Turkey,

İzmir Bozyaka Training and Research Hospital, Clinic of Hematology, İzmir, Turkey

Phone : +905058861126

E-mail : med.can@hotmail.com ORCID: orcid.org/0000-0002-5600-3169
Received/Geliş tarihi: April 4, 2021 Accepted/Kabul tarihi: June 22, 2021 


\section{Introduction}

Primary immune thrombocytopenia (ITP) is an acquired autoimmune disease characterized by isolated thrombocytopenia caused by T-cell-mediated platelet destruction, with immunoglobulin $\mathrm{G}$ autoantibodies binding to platelets and megakaryocytes, and megakaryocyte dysfunction. Patients may present with petechiae, purpura, mucosal bleeding, and lifethreatening organ bleeding $[1,2,3]$. The aim of treatment is to preventserious or life-threatening bleeding. Treatment modalities employed in ITP target various stages in its pathophysiology, including the inhibition of autoantibody synthesis, modulation of T-cell activity, and stimulation of platelet production. While first-line treatments mainly focus on inhibiting autoantibodies and platelet destruction, second- and third-line treatments include immunosuppression, splenectomy, and megakaryocyte stimulation for increased platelet production [4].

Splenectomy is an effective treatment choice for steroidrefractory or steroid-dependent ITP because the spleen is the major site of platelet clearance. Macrophages express the Fc $\gamma \mathrm{R}$ function in the phagocytosis of antibody-coated platelets via SYK signaling pathways $[5,6]$. They also present antigenic peptides, including glycoproteins $\mathrm{Ila} / \mathrm{Ill} \mathrm{b}$ and $\mathrm{Ib} / \mathrm{IX}$, to CD4+ T cells, causing activation and expansion of autoreactive $\mathrm{B}$ - and T-cells $[7,8]$. The spleen also acts as a reservoir for long-lived plasma cells producing antiplatelet antibodies [9]. However, there is no reliable predictor for splenectomy response. Considering the associated risk of infection and cardiovascular complications, splenectomy is being replaced by immunosuppressive agents and thrombopoietin receptor agonists (TPO-RAs) as the secondline treatment of ITP [10].

The TPO-RAs romiplostim and eltrombopag have been widely used since 2008 [11]. These agents bind to the TPO receptor, cause conformational changes, and activate the JAK2/STAT5 pathway, increasing megakaryocyte progenitor proliferation and platelet production $[12,13]$. Randomized controlled studies with TPO-RAs have reported response rates of 50\% to $90 \%$, as well as efficiency in preventing bleeding and decreased need to use additional medication. Data on toxicity indicate reversible reticulin fibrosis and increased risk of venous thromboembolism (VTE) [11].

Studies that directly compare the long-term efficacy of secondline treatments for ITP are limited and treatment decisions are therefore mostly patient-based. In this study, we aimed to compare the efficiency and toxicities of splenectomy and eltrombopag, a TPO-RA, as second-line treatments for ITP.

\section{Materials and Methods}

In our study, we retrospectively analyzed patients who were diagnosed with ITP after the evaluation of complete blood count, peripheral blood smear, blood biochemistry, viral serologies including human immunodeficiency virus and hepatitis C virus, abdominal sonography, and antinuclear antibody testing and who were followed between 2015 and 2020. Bone marrow aspiration and biopsy were performed for patients as deemed necessary by the clinician to confirm the diagnosis of ITP. Among these cases, patients who were steroidresistant, who were steroid-refractory, or who experienced relapse after response and who had undergone splenectomy or received eltrombopag treatment as second-line or third-line therapy as the next step after only splenectomy were included in the study. Included subjects were divided into splenectomy and eltrombopag groups. For subgroup analyses, patients receiving eltrombopag were further stratified according to whether they received eltrombopag as the second or third line of treatment.

Patient data were recorded, including age, sex, ITP bleeding score, white blood cell (WBC) count, neutrophil and lymphocyte counts, hemoglobin level, mean corpuscular volume (MCV), platelet count, mean platelet volume (MPV), serum creatinine, aspartate aminotransferase, alanine aminotransferase, and lactate dehydrogenase levels at the time of splenectomy or initiation of eltrombopag therapy, as well as the dates of diagnosis and last visit. The ITP bleeding score was assessed according to the World Health Organization Bleeding Scale [14]. Cases were classified using a simple five-point scale in which no bleeding was scored as 0 , petechiae as grade 1 , mild blood loss as grade 2 , gross blood loss as grade 3, and debilitating blood loss as grade 4. The following comparisons between the splenectomy and eltrombopag groups were also performed: time to achieve response; response at the $1^{\text {st }}, 3^{\text {rd }}, 6^{\text {th }}, 12^{\text {th }}$, and $24^{\text {th }}$ months; total duration of response; and complications. Response evaluation was performed according to the American Society of Hematology's 2009 International Working Group Report [15]. Platelet count below $30,000 / \mathrm{mm}^{3}$ was considered as no response, above $30,000 / \mathrm{mm}^{3}$ as response, and above $100,000 / \mathrm{mm}^{3}$ as complete response.

The compliance of the study with ethical rules was confirmed by the İzmir Bozyaka Training and Research Hospital Ethics Committee and approval was granted. Also, the consent was obtained from the volunteers included in the study.

\section{Statistical Analysis}

SPSS 21 was used for statistical tests. Data were represented as mean \pm standard deviation for numeric variables and as frequency and percentage for categorical variables. Normality of numeric variables was assessed by Shapiro-Wilk test. Comparisons of normally distributed variables were performed using t-tests, while the Mann-Whitney $\mathrm{U}$ test was used for nonnormally distributed nonparametric variables. 
The chi-square test was used to determine whether there was a relationship and dependency between two variables. Values of $p<0.05$ were considered statistically significant.

\section{Results}

Eighty-five patients were included in the study. Bone marrow aspiration and biopsy were performed for 67 patients who required confirmation of the diagnosis of ITP. Among those, 49 were female and 36 were male. The median ages of the patients in the splenectomy and eltrombopag groups were 43.2 and 50.5 years, respectively. There were 38 patients in the splenectomy group and 47 patients in the eltrombopag group. There was no statistically significant difference between the two groups in terms of age, sex, comorbidities, bleeding score, WBC count, neutrophil and lymphocyte counts, hemoglobin, $\mathrm{MCV}$, or platelet count. Characteristics of the treatment groups are summarized in Table 1.
Table 2 presents data on the time to achieve response $(R)$ or complete response (CR) in the second line of treatment; R/CR at the $1^{\text {st }}, 3^{\text {rd }}, 6^{\text {th }}, 12^{\text {th }}$, and $24^{\text {th }}$ months of second-line therapy; and the total duration of $\mathrm{R} / \mathrm{CR}$ of the treatment groups. Time to $\mathrm{R} / \mathrm{CR}$ was significantly shorter in the splenectomy group $(p=0.001)$. The $R / C R$ rate at the $1^{\text {st }}$ month was also significantly higher in the splenectomy group $(p=0.023)$. However, $R / C R$ rates at the $3^{\text {rd }}, 6^{\text {th }}, 12^{\text {th }}$, and $24^{\text {th }}$ months and total duration of R/CR did not exhibit statistically significant differences between the groups.

One patient in the splenectomy group developed deep vein thrombosis. In the eltrombopag group, one patient experienced headache, one patient had elevated liver enzymes, one patient developed bone marrow fibrosis, one patient developed chronic myelomonocytic leukemia (CMML), one patient developed basal cell carcinoma, and one patient developed pancreatic cancer. There was no statistically significant difference in adverse events

\begin{tabular}{|c|c|c|c|c|}
\hline \multicolumn{2}{|c|}{ 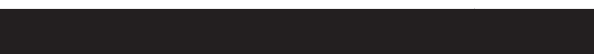 } & Splenectomy & Eltrombopag & $\mathbf{p}$ \\
\hline \multicolumn{2}{|c|}{ Median age, years (range) } & $43.2(18-76)$ & $50.5(23-89)$ & 0.056 \\
\hline \multirow{2}{*}{ Sex, $n$} & Female & 28 & 21 & \multirow{2}{*}{0.329} \\
\hline & Male & 10 & 26 & \\
\hline \multirow{2}{*}{ Comorbidities, n } & Yes & 16 & 27 & \multirow{2}{*}{0.160} \\
\hline & No & 22 & 20 & \\
\hline \multirow{4}{*}{ Bleeding score, $n$} & 0 & 12 & 24 & \multirow{4}{*}{0.223} \\
\hline & 1 & 12 & 14 & \\
\hline & 2 & 12 & 8 & \\
\hline & 3 & 2 & 1 & \\
\hline \multicolumn{2}{|c|}{$\mathrm{WBCs} / \mu \mathrm{L}$, mean $\pm \mathrm{SD}$} & $8750.0 \pm 2758.8$ & $8970.7 \pm 3679.4$ & 0.913 \\
\hline \multicolumn{2}{|c|}{ Neutrophils/ $\mu \mathrm{L}$, mean $\pm \mathrm{SD}$} & $5910.5 \pm 250.8$ & $5956.5 \pm 352.3$ & 0.953 \\
\hline \multicolumn{2}{|c|}{ Lymphocytes/ $\mu \mathrm{L}$, mean \pm SD } & $2063.1 \pm 685.5$ & $2437.3 \pm 1214.0$ & 0.128 \\
\hline \multicolumn{2}{|c|}{ Hemoglobin, g/dL, mean \pm SD } & $12.2 \pm 2.1$ & $12.8 \pm 2.8$ & 0.214 \\
\hline \multicolumn{2}{|c|}{$\mathrm{MCV}, \mathrm{fL}$, mean $\pm \mathrm{SD}$} & $84.3 \pm 8.0$ & $81.5 \pm 6.9$ & 0.125 \\
\hline \multicolumn{2}{|c|}{ Platelets $/ \mu \mathrm{L}$, mean $\pm \mathrm{SD}$} & $14,800 \pm 8900$ & $14,300 \pm 12,300$ & 0.833 \\
\hline
\end{tabular}

\begin{tabular}{|l|l|l|l|}
\hline \multicolumn{4}{|l|}{ Table 2. Comparison of treatment response between splenectomy and eltrombopag groups. } \\
\hline & Splenectomy & Eltrombopag & $\mathbf{p}$ \\
\hline Time to achieve R/CR in second line treatment, days & $1.9(0-9)$ & $19.1(0-126)$ & $\mathbf{0 . 0 0 1}$ \\
\hline R/CR at the $\mathbf{1}^{\text {st }}$ month & $100 \%$ & $85.7 \%$ & $\mathbf{0 . 0 2 3}$ \\
\hline R/CR at the $\mathbf{3}^{\text {rd }}$ month & $86.8 \%$ & $85.7 \%$ & 0.403 \\
\hline R/CR at the $\mathbf{6}^{\text {th }}$ month & $76.3 \%$ & $85.7 \%$ & 0.410 \\
\hline R/CR at the $\mathbf{1 2}^{\text {th }}$ month & $71.0 \%$ & $61.9 \%$ & 0.680 \\
\hline R/CR at the $\mathbf{2 4}^{\text {th }}$ month & $57.8 \%$ & $55.3 \%$ & 0.677 \\
\hline Total duration of R/CR, months & $43.0(1-123)$ & $34.9(0-122)$ & 0.341 \\
\hline Complications, $\mathbf{n}$ & 1 & 6 & 0.105 \\
\hline R: Response; CR: complete response. & & \\
\hline
\end{tabular}


between treatment groups $(p=0.105)$. Bone marrow fibrosis was detected in the patient who underwent bone marrow biopsy 3 years after eltrombopag treatment because platelet increase could not be achieved despite increasing the dose of eltrombopag. The diagnosis of CMML was made 14 months after the patient started eltrombopag. A blast count below 5\% was considered as CMML-0 and the patient was followed without treatment.

Patients receiving eltrombopag were stratified according to whether they received the treatment in the second or third line. Table 3 provides data on age and sex; comorbidities; bleeding score; WBC, neutrophil, and lymphocyte counts; hemoglobin, $M C V, M P V$, and platelet count; time to achieve $R / C R ; R / C R$ at the $1^{\text {st }}, 3^{\text {rd }}, 6^{\text {th }}, 12^{\text {th }}$, and $24^{\text {th }}$ months of second-line treatment; and the total duration of $\mathrm{R} / \mathrm{CR}$. Patients who received eltrombopag in the third line had significantly higher WBC counts ( $p=0.002)$. On the other hand, no significant difference was observed between the groups in terms of age, sex, comorbidities, bleeding score, neutrophil and lymphocyte counts, hemoglobin, MCV, or platelet count. The $R / C R$ rates at the $1^{\text {st }}, 3^{\text {rd }}, 6^{\text {th }}, 12^{\text {th }}$, and $24^{\text {th }}$ months and the total duration of $\mathrm{R} / \mathrm{CR}$ also did not exhibit statistically significant differences between the groups.
Eltrombopag treatment was discontinued with no tapering due to adverse effects or the patient's refusal for various reasons in 20 patients after a median of 54.1 months (range: 1-151). Among them, 12 patients (60\%) did not experience a loss of response. The median duration of eltrombopag treatment was 25.6 (range: 2-64) months and median follow-up was 67.9 (range: 20-151) months in these patients. The follow-up period after discontinuation of eltrombopag was 12.4 months, median platelet count was $159,000 / \mathrm{mm}^{3}$, and bleeding score was 0.0 .

\section{Discussion}

As highlighted in the updated international consensus report, initial treatments for patients with newly diagnosed ITP are usually corticosteroid-based regimens, intravenous immunoglobulin (IVIg), and anti-D. However, the most commonly preferred treatments are corticosteroids. IVlg can also be added to the treatment for patients with active bleeding, patients who are scheduled to undergo emergency interventions, or patients who experience adverse events with glucocorticoids, even though this approach is not standardized $[16,17,18]$.

Because there are no randomized controlled studies that directly compare second-line treatment options in ITP, treatment

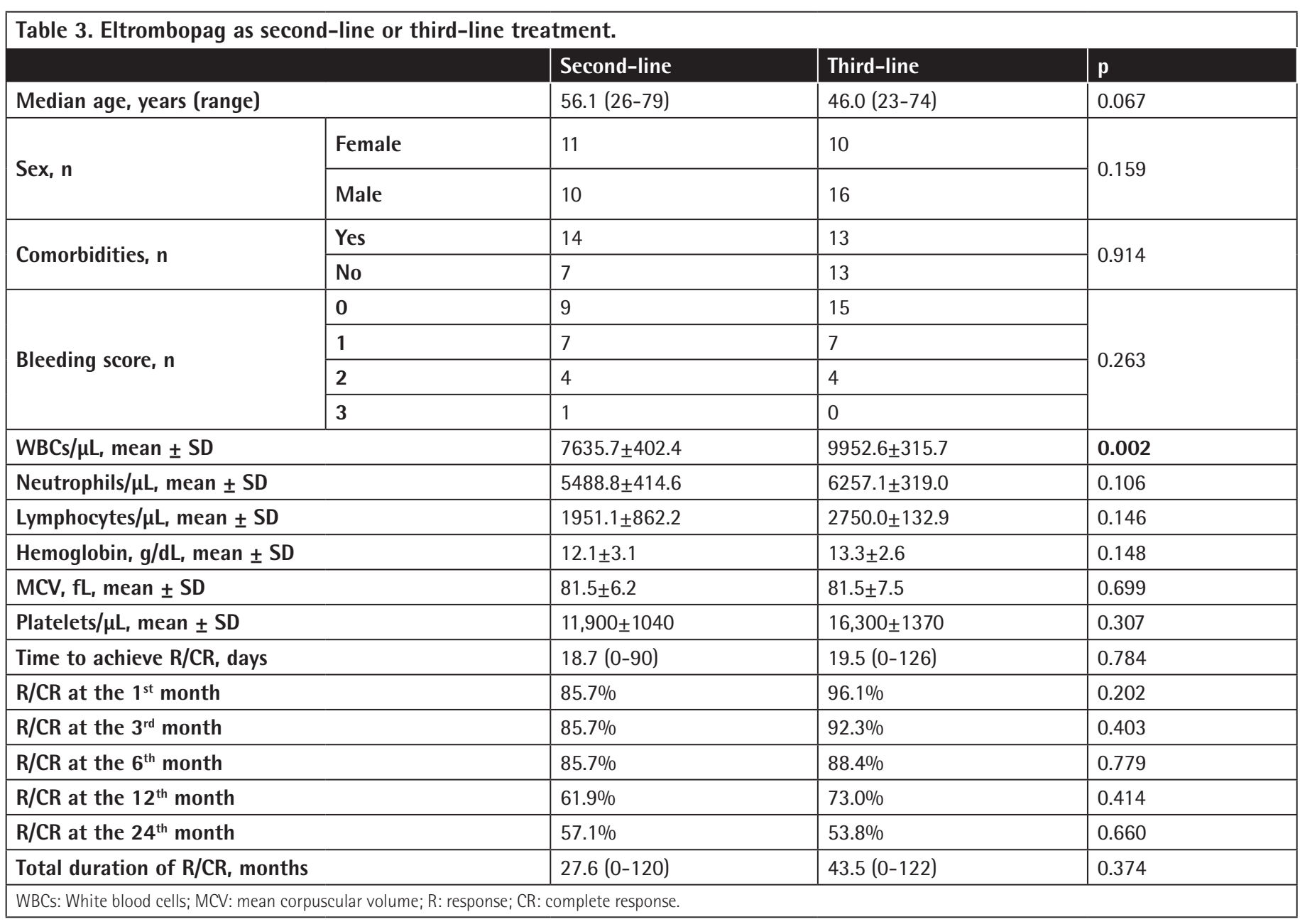


decisions are mostly based on patient characteristics and clinical preferences. Second-line medical treatments supported by robust evidence are rituximab and TPO-RAs. Splenectomy is still also preferred as a surgical option today $[18,19,20]$.

Splenectomy is among the second-line treatment options with the greatest likelihood of achieving long-term remission and changing the course of the disease [21]. Provan et al. [18] recommended waiting at least 12 months after the diagnosis to rule out possible spontaneous remission. As new drugs are available for ITP, splenectomy is often postponed. If the patient is working in a risky profession or has a thrombotic history or immunosuppression, splenectomy is considered as the second line. In developing countries, and especially for younger patients, it is still recommended for financial reasons and the difficulties in obtaining novel drugs. Kojouri et al. [22] conducted a systematic review of 47 case series including 2623 adult patients undergoing splenectomy and found rates of $66 \%$ complete response and $88 \%$ overall response. The mean duration of response was approximately 12 years in this patient group [22]. Platelet count often tends to rise within 1 to 2 days after splenectomy, while a delayed response can be observed at up to 8 weeks [23]. The only clinical parameter predicting splenectomy response is the patient's age, with younger patients achieving higher response rates [22]. Even though there is no distinct age cut-off, splenectomy was recommended for patients younger than 50 years in two different studies $[24,25]$. In our study, the median age of the patients in the splenectomy group was 43.2 years. The higher median age of the patients in the eltrombopag group was due to elderly patients ineligible for splenectomy inevitably being in this treatment arm.

The most common complications after splenectomy, which is an irreversible procedure, are infections and venous thromboembolism. In the review by Kojouri et al. [22], complications occurred in 88 of 921 patients (9.6\%) undergoing laparoscopic splenectomy and in 318 of 2465 patients (12.9\%) undergoing open splenectomy. The risk of infection is highest in the early postoperative period. In another series of 3812 patients undergoing splenectomy for various indications, the rate of infections was $10.2 \%$ in the first 90 days [26]. However, this rate declines to $1 \%-3 \%$ in the long term [27]. In our study, no infectious side effects were found. The risk of VTE also increases after splenectomy. In the aforementioned cohort of 3812 patients undergoing splenectomy, the risk of VTE in the first year was reported to be $1.9 \%$. Observed thromboses in that study were deep vein thrombosis in half of the patients, pulmonary embolism in a quarter, and portal or splenic vein thrombosis in the remaining quarter [26]. Considering these potential complications as well as the possibility of spontaneous remission in ITP, postponing splenectomy for 6 to 12 months after diagnosis may help avoid needless interventions. However, this duration may be shortened for symptomatic patients with severe thrombocytopenia [28]. In our study, response was observed at a mean of 1.9 days in 38 patients undergoing splenectomy and this response was durable for a mean of 43 months. One patient (2.6\%) experienced deep vein thrombosis.

Studies assessing the efficiency of eltrombopag have reported overall response rates of about $80 \%$, including temporary responses. The RAISE study, which randomized 197 adult patients into eltrombopag and placebo arms, showed that the mean platelet count of patients receiving eltrombopag was $74,000 / \mathrm{mm}^{3}$ and their response rate was $79 \%$. This rate showed no difference among patients who underwent splenectomy and those who received other therapies prior to eltrombopag. The long-term response rate was $51 \%$ in patients with splenectomy and 66\% in patients without splenectomy [29]. In another study with 110 adult patients, rates of response to eltrombopag and a placebo were found to be $59 \%$ and $16 \%$, respectively [30]. The EXTEND study revealed that the 3-year response rates of 299 patients using eltrombopag were $80 \%$ for splenectomized and 89.3\% for non-splenectomized patients [31]. In a recent study assessing real-life data, the researchers reported that rates of response to eltrombopag were not affected by factors including splenectomy status or initial platelet count. Six of those patients stopped eltrombopag after a median sustained response of 796 days and remained in remission for a median follow-up of 624 days [32]. Similarly, González-López et al. [33] reported that $51 \%$ of patients remained in remission in the $6^{\text {th }}$ month after eltrombopag cessation after sustained response.

Eltrombopag is usually well tolerated. The most common side effects are headache, gastrointestinal complaints, elevated liver enzymes, thrombosis, and bone marrow fibrosis. In the EXTEND study, 14\% of patients had to cease medication due to adverse events. Among these, hepatobiliary adverse events were observed in 7 patients, cataract in 4 patients, deep vein thrombosis in 3 patients, cerebral infarction in 2 patients, headache in 2 patients, and myelofibrosis in 2 patients. The rate of thromboembolic events and hepatobiliary adverse events did not show any increase with 1 year of therapy [29,34]. In our study, median duration of response was 34.9 months in patients receiving eltrombopag and only 55\% maintained response into the $2^{\text {nd }}$ year. There was no significant difference in the response rates of patients with and without a history of splenectomy prior to eltrombopag. Twelve of 20 patients who stopped eltrombopag treatment remained in remission. The observed adverse events were consistent with those reported in the literature; however, malignancy development in $3(6.3 \%)$ patients was noteworthy. The EXTEND study did not reveal a significant difference between the treatment and placebo arms in terms of malignancies [34]. In a multicenter study from Turkey that reported the 12-month data of 40 patients on eltrombopag, there were also no eltrombopag-associated malignancies [35]. We could not identify a direct association 
between the observed malignancies and eltrombopag use, but we think that these malignancies may be incidental due to the higher median age in the eltrombopag group. Furthermore, a statistically significant difference was found in our study in terms of pretreatment leukocyte counts between administration of eltrombopag as second-line and as third-line treatment. This difference may be attributable to splenectomy, as the patients receiving third-line eltrombopag had previously undergone splenectomy.

\section{Conclusion}

Comparing the splenectomy and eltrombopag arms of the present study, even though time to achieve response and the response rate at the $1^{\text {st }}$ month were in favor of splenectomy, this advantage disappeared when overall response rates and response rate at the $2^{\text {nd }}$ year were considered. However, more adverse events were observed in the eltrombopag group. Observed malignancies in 3 patients are inconsistent with the reported data in the literature. Using eltrombopag in the second or third line of therapy does not yield any difference in terms of time to achieve response. The overall response rate was higher when eltrombopag was used as the third-line treatment after splenectomy compared to second-line treatment, but this difference did not reach statistical significance. Randomized prospective studies comparing treatment options such as splenectomy, immunosuppressive therapies, and eltrombopag head-to-head are required for the standardization of second-line and more advanced therapies for immune thrombocytopenia.

\section{Ethics}

Ethics Committee Approval: The compliance of the study with ethical rules was confirmed by the İzmir Bozyaka Training and Research Hospital Ethics Committee and approval was granted.

Informed Consent: Consent was obtained from the volunteers included in the study.

\section{Authorship Contributions}

Surgical and Medical Practices: M.C.U., E.E.D., E.T.E.; Concept: S.N., R.E., O.B.; Design: S.N., R.E.; Data Collection or Processing: M.C.U., E.E.D., E.T.E.; Analysis or Interpretation: M.C.U., R.E., O.B.; Literature Search: M.C.U., N.N.; Writing: N.N.

Conflict of Interest: No conflict of interest was declared by the authors.

Financial Disclosure: The authors declared that this study received no financial support.

\section{References}

1. Khodadi E, Asnafi AA, Shahrabi S, Shahjahani M, Saki N. Bone marrow niche in immune thrombocytopenia: a focus on megakaryopoiesis. Ann Hematol 2016;95:1765-1776.
2. Olsson $B$, Andersson $P O$, Jernås $M$, Jacobsson $S$, Carlsson $B$, Carlsson LM, Wadenvik H. T-cell-mediated cytotoxicity toward platelets in chronic idiopathic thrombocytopenic purpura. Nat Med 2003;9:1123-1124.

3. Moulis G, Palmaro A, Montastruc JL, Godeau B, Lapeyre-Mestre M, Sailler L. Epidemiology of incident immune thrombocytopenia: a nationwide population-based study in France. Blood 2014;124:3308-3315.

4. Blickstein D. Treatment of immune thrombocytopenic purpura in adults: update. Harefuah 2019;15:196-199.

5. Audia S, Santegoets K, Laarhoven AG, Vidarsson G, Facy O, Ortega-Deballon P, Samson M, Janikashvili N, Saas P, Bonnotte B, Radstake TR. Fc $\gamma$ receptor expression on splenic macrophages in adult immune thrombocytopenia. Clin Exp Immunol 2017;188:275-282.

6. Podolanczuk A, Lazarus AH, Crow AR, Grossbard E, Bussel JB. Of mice and men: an open-label pilot study for treatment of immune thrombocytopenic purpura by an inhibitor of Syk. Blood 2009;113:3154-3160.

7. Kuwana M, Okazaki Y, Kaburaki J, Kawakami Y, Ikeda Y. Spleen is a primary site for activation of platelet-reactive $T$ and $B$ cells in patients with immune thrombocytopenic purpura. J Immunol 2002;168:3675-3682.

8. Roark JH, Bussel JB, Cines DB, Siegel DL. Genetic analysis of autoantibodies in idiopathic thrombocytopenic purpura reveals evidence of clonal expansion and somatic mutation. Blood 2002;100:1388-1398.

9. Mahévas $M$, Patin P, Huetz F, Descatoire $M$, Cagnard N, Bole-Feysot $C$, Le Gallou S, Khellaf M, Fain O, Boutboul D, Galicier L, Ebbo M, Lambotte O, Hamidou M, Bierling P, Godeau B, Michel M, Weill JC, Reynaud CA. B cell depletion in immune thrombocytopenia reveals splenic long-lived plasma cells. J Clin Invest 2013;123:432-442.

10. Chaturvedi S, Arnold DM, McCrae KR. Splenectomy for immune thrombocytopenia: down but not out. Blood 2018;131:1172-1182.

11. Ghanima W, Cooper N, Rodeghiero F, Godeau B, Bussel JB. Thrombopoietin receptor agonists: ten years later. Haematologica 2019;104:1112-1123.

12. Broudy VC, Lin NL. AMG531 stimulates megakaryopoiesis in vitro by binding to Mpl. Cytokine 2004;25:52-60.

13. 13. Erickson-Miller CL, Delorme $E$, Tian SS, Hopson CB, Landis AJ, Valoret El, Sellers TS, Rosen J, Miller SG, Luengo JI, Duffy KJ, Jenkins JM. Preclinical activity of eltrombopag (SB-497115), an oral, nonpeptide thrombopoietin receptor agonist. Stem Cells 2009;27:424-430.

14. Fogarty PF, Tarantino MD, Brainsky A, Signorovitch J, Grotzinger KM. Selective validation of the WHO Bleeding Scale in patients with chronic immune thrombocytopenia. Curr Med Res Opin 2012;28:79-87.

15. Rodeghiero F, Stasi R, Gernsheimer T, Michel M, Provan D, Arnold DM, Bussel JB, Cines DB, Chong BH, Cooper N, Godeau B, Lechner K, Mazzucconi MG, McMillan R, Sanz MA, Imbach P, Blanchette V, Kühne T, Ruggeri M, George JN. Standardization of terminology, definitions and outcome criteria in immune thrombocytopenic purpura of adults and children: report from an international working group. Blood 2009;12;113:2386-2393.

16. Matschke J, Müller-Beissenhirtz H, Novotny J, Vester I, Hertenstein B, Eisele $L$, Lax $H$, Ose $C$, Dührsen U. A randomized trial of daily prednisone versus pulsed dexamethasone in treatment-naïve adult patients with immune thrombocytopenia: EIS 2002 study. Acta Haematol 2016;136:101-107.

17. Salib M, Clayden R, Clare R, Wang G, Warkentin TE, Crowther MA, Lim W, Nazi I, Kelton JG, Arnold DM. Difficulties in establishing the diagnosis of immune thrombocytopenia: an agreement study. Am J Hematol 2016;91:E327-329.

18. Provan D, Arnold DM, Bussel JB, Chong BH, Cooper N, Gernsheimer T, Ghanima W, Godeau B, González-López TJ, Grainger J, Hou M, Kruse C, McDonald V, Michel M, Newland AC, Pavord S, Rodeghiero F, Scully M, Tomiyama Y, Wong RS, Zaja F, Kuter DJ. Updated international consensus report on the investigation and management of primary immune thrombocytopenia. Blood Adv 2019;3:3780-3817.

19. Bylsma LC, Fryzek JP, Cetin K, Callaghan F, Bezold C, Mehta B, Wasser JS. Systematic literature review of treatments used for adult immune 
thrombocytopenia in the second-line setting. Am J Hematol 2019;94:118132.

20. Cuker A. Transitioning patients with immune thrombocytopenia to secondline therapy: challenges and best practices. Am J Hematol 2018;93:816-823.

21. George JN. Management of immune thrombocytopenia--something old, something new. N Engl J Med 2010;363:1959-1961.

22. Kojouri K, Vesely SK, Terrell DR, George JN. Splenectomy for adult patients with idiopathic thrombocytopenic purpura: a systematic review to assess long-term platelet count responses, prediction of response, and surgical complications. Blood 2004;104:2623-2634.

23. Gigot JF, Healy ML, Ferrant A, Michaux JL, Njinou B, Kestens PJ. Laparoscopic splenectomy for idiopathic thrombocytopenic purpura. Am J Surg 2004;187:720-723.

24. Duperier T, Brody F, Felsher J, Walsh RM, Rosen M, Ponsky J. Predictive factors for successful laparoscopic splenectomy in patients with immune thrombocytopenic purpura. Arch Surg 2004;139:61-66.

25. Tastaldi L, Krpata DM, Prabhu AS, Petro CC, Haskins IN, Perez AJ, Alkhatib H, Colturato I, Tu C, Lichtin A, Rosen MJ, Rosenblatt S. Laparoscopic splenectomy for immune thrombocytopenia (ITP): long-term outcomes of a modern cohort. Surg Endosc 2019;33:475-485.

26. Thomsen RW, Schoonen WM, Farkas DK, Riis A, Jacobsen J, Fryzek JP, Sørensen HT. Risk for hospital contact with infection in patients with splenectomy: a population-based cohort study. Ann Intern Med 2009;151:546-555.

27. Bisharat N, Omari H, Lavi I, Raz R. Risk of infection and death among postsplenectomy patients. J Infect 2001;43:182-186.

28. Rodeghiero F. A critical appraisal of the evidence for the role of splenectomy in adults and children with ITP. Br J Haematol 2018;181:183-195.

29. Cheng G, Saleh MN, Marcher C, Vasey S, Mayer B, Aivado M, Arning M, Stone NL, Bussel JB. Eltrombopag for management of chronic immune thrombocytopenia (RAISE): a 6-month, randomised, phase 3 study. Lancet 2011;377:393-402.
30. Bussel JB, Provan D, Shamsi T, Cheng G, Psaila B, Kovaleva L, Salama A, Jenkins JM, Roychowdhury D, Mayer B, Stone N, Arning M. Effect of eltrombopag on platelet counts and bleeding during treatment of chronic idiopathic thrombocytopenic purpura: a randomised, double-blind, placebo-controlled trial. Lancet 2009;373:641-648.

31. Saleh MN, Bussel JB, Cheng G, Meyer O, Bailey CK, Arning M, Brainsky A; EXTEND Study Group. Safety and efficacy of eltrombopag for treatment of chronic immune thrombocytopenia: results of the long-term, open-label EXTEND study. Blood 2013;121:537-545.

32. Mishra K, Pramanik $S$, Jandial $A$, Sahu KK, Sandal R, Ahuja A, Yanamandra U, Kumar R, Kapoor R, Verma T, Sharma S, Singh J, Das S, Chatterjee T, Sharma A, Nair V. Real-world experience of eltrombopag in immune thrombocytopenia. Am J Blood Res 2020;10:240-251.

33. González-López TJ, Alvarez-Román MT, Pascual C, Sánchez-González $B$, Fernández-Fuentes $F$, Jarque I, Pérez-Rus G, Pérez-Crespo $S$, Bernat $S$, Hernández-Rivas JA, Andrade MM, Cortés $M$, Gómez-Nuñez $M$, Olivera $P$, Martínez-Robles $V$, Fernández-Rodríguez $A$, Fuertes-Palacio MA, Fernández-Miñano $C$, de Cabo E, Fisac R, Aguilar C, Bárez A, Peñarrubia MJ, Garcia-Frade L, González-Porras JR. Eltrombopag safety and efficacy for primary chronic immune thrombocytopenia in clinical practice. Eur J Haematol 2016;97:297-302.

34. Wong RSM, Saleh MN, Khelif A, Salama A, Portella MSO, Burgess P, Bussel JB. Safety and efficacy of long-term treatment of chronic/persistent ITP with eltrombopag: final results of the EXTEND study. Blood 2017;130:25272536.

35. Özdemirkıran F, Payzın B, Kiper HD, Kabukçu S, Akgün Çağlıyan G, Kahraman S, Sevindik ÖG, Ceylan C, Kadıköylü G, Şahin F, Keskin A, Arslan Ö, Özcan MA, Kabukçu G, Görgün G, Bolaman Z, Büyükkeçeci F, Bilgir O, Alacacıoğlu I, Vural F, Tombuloğlu M, Gökgöz Z, Saydam G. Eltrombopag for the treatment of immune thrombocytopenia: the Aegean Region of Turkey experience. Turk J Hematol 2015;32:323-328. 